\title{
Minireview
}

\section{Angiogenesis and Vasculogenesis in Treatment of Cardiovascular Disease}

\author{
Alain Rivard and Jeffrey $M$. Isner \\ Departments of Medicine (Cardiology) and Biomedical Research, St. \\ Elizabeth's Medical Center, Tufts University School of Medicine, \\ Boston, Massachusetts, U.S.A.
}

\section{Introduction}

Vasculogenesis and angiogenesis are the processes responsible for the development of the circulatory system, the first functional unit in the developing embryo (1). Postnatal angiogenesis is encountered in pathologic situations such as diabetic retinopathy, arthritis, and, most notably, tumor growth and metastasis. It is also involved in therapeutic angiogenesis: the development of collateral blood vessels supplying ischemic tissues, either endogenously or in response to administration of growth factors.

\section{Therapeutic Angiogenesis}

Angiogenesis is defined as the extension of the primitive vasculature through sprouting of new capillaries from the pre-existing network. It is a complex process that includes activation, migration, and proliferation of endothelial cells (2). The therapeutic implications of angiogenic growth factors were identified by the pioneering work of Folkman and colleagues over two decades ago (3). Their work documented the extent to which tumor development was dependent upon neovascularization and suggested that this relationship might involve angiogenic growth factors that were specific for neoplasms. More recent investigations have established the feasibility of using recombinant formulations of such angiogenic growth factors to expedite and/or augment collateral artery development in animal models of myocardial and hindlimb ischemia. This novel strategy for the treatment of vascular

\footnotetext{
Address correspondence and reprint requests to: Dr. Jeffrey M. Isner, St. Elizabeth's Medical Center, 736 Cambridge Street, Boston, MA 02135, U.S.A. Phone: (617) 789-2392; Fax: (617) 779-6362; E-mail: jisner@opal.tufts.edu
}

insufficiency has been termed "therapeutic angiogenesis" (4).

\section{Therapeutic Angiogenesis Achieved by Recombinant Protein Administration}

The angiogenic growth factors first employed for the purpose of therapeutic angiogenesis comprised members of the fibroblast growth factor (FGF) family. Baffour et al. administered bFGF in daily intramuscular (IM) doses of 1 or $3 \mu \mathrm{g}$ to rabbits with acute hindlimb ischemia; at the completion of 14 days of treatment, angiography and necropsy measurement of capillary density showed evidence of augmented collateral vessels in the lower limb, compared with controls (5). $\mathrm{Pu}$ et al. used aFGF to treat rabbits in which the acute effects of surgically induced hindlimb ischemia were allowed to subside for 10 days before beginning a 10-day course of daily 4-mg IM injections; at the completion of 30 days follow-up, both angiographic and hemodynamic evidence of collateral development was superior to that in ischemic controls treated with IM saline (6). Yanagisawa-Miwa et al. likewise demonstrated the feasibility of bFGF for salvage of infarcted myocardium, but in this case growth factor was administered intra-arterially at the time of coronary occlusion, followed $6 \mathrm{hr}$ later by a second intra-arterial bolus (7).

Evidence that vascular endothelial growth factor (VEGF) stimulates angiogenesis in vivo has been developed in experiments performed on rat and rabbit cornea $(8,9)$, the chorioallantoic membrane (10), and the rabbit bone graft model (9). The finding that VEGF could be employed to achieve angiogenesis that was therapeutic was first demonstrated by Takeshita et al. (4). The 165 amino acid isoform of VEGF 
$\left(\mathrm{VEGF}_{165}\right)$ was administered as a single intraarterial bolus to the internal iliac artery of rabbits in which the ipsilateral femoral artery was excised to induce unilateral hindlimb ischemia. The severity of hindlimb ischemia in this animal model has been shown in previous studies to include reduced $\mathrm{TcO}_{2}(5)$, increased femoral venous lactate (11), and skeletal muscle necrosis (5). Doses of 500-1000 $\mu \mathrm{g}$ of VEGF produced statistically significant augmentation of angiographically visible collateral vessels, and histologically identifiable capillaries; consequent amelioration of the hemodynamic deficit in the ischemic limb was significantly greater in animals receiving VEGF than in nontreated controls (calf blood pressure ratio $=$ $0.75 \pm 0.14$ versus $0.48 \pm 0.19, p<0.05$ ) Serial (baseline, as well as 10 and 30 days postVEGF) angiograms disclosed progressive linear extension of the collateral artery of origin (stem artery) to the distal point of parent-vessel (reentry artery) reconstitution in 7 of 9 VEGFtreated animals. Similar results were achieved in a separate series of experiments in which VEGF was administered by an IM route daily for 10 days (12). By 30 days post-VEGF ${ }_{165}$, flow at rest, as well as maximum flow velocity and maximum blood flow provoked by $2 \mathrm{mg}$ papaverine, were all significantly higher in the VEGFtreated group (13). These findings thus established proof of principle for the concept that the angiogenic activity of VEGF is sufficiently potent to achieve therapeutic benefit. There is now abundant data in animal models to support the potential utility of recombinant protein therapy in myocardial angiogenesis $(7,14-20)$ and for lower-extremity vascular insufficiency (4$6,12,21-25)$. In a recent report from Schumacher et al. (26), induction of neoangiogenesis in patients with three-vessel coronary disease was performed by direct intramyocardial injection of recombinant FGF1 protein at the time of coronary artery bypass surgery. The development of new vessels around the site of injection was demonstrated angiographically. The net clinical benefit of FGF administration in this type of experiment will probably be difficult to evaluate because two different procedures (bypass surgery and recombinant protein administration) were performed simultaneously. However, this report suggests that myocardial angiogenesis can be performed in humans with severe coronary artery disease.
Therapeutic Angiogenesis Achieved by Gene Transfer

No recombinant protein formulation of any of the three principal VEGF isoforms or any other angiogenic cytokine is currently approved or available for human clinical application. Gene transfer constitutes an alternative strategy for accomplishing therapeutic angiogenesis in patients with limb ischemia or severe coronary artery disease. In the case of VEGF, this is a particularly appealing strategy because the VEGF gene encodes a signal sequence that permits the protein to be naturally secreted from intact cells (27).

GENE TRANSFER USING PLASMIDS ("NAKED DNA"). Previous studies from our laboratory $(28,29)$ have indicated that arterial gene transfer of cDNA encoding for a secreted protein could potentially yield meaningful biological outcomes in spite of a low transfection efficiency. We therefore performed preclinical animal studies to establish the feasibility of site-specific gene transfer of the 121 amino acid isoform of human VEGF $\left(\right.$ phVEGF $\left._{121}\right)$, phVEGF $_{165}$, and phVEGF 189 applied to the hydrogel polymer coating of an angioplasty balloon (30), and delivered percutaneously to the iliac artery of rabbits in which the femoral artery had been excised to cause unilateral hindlimb ischemia (11).

Site-specific transfection of phVEGF 165 was confirmed by analysis of the transfected internal iliac arteries using reverse transcriptase-polymerase chain reaction (RT-PCR) (31) and then sequencing the RT-PCR product. Augmented development of collateral vessels was documented by serial angiograms in vivo, and increased capillary density at necropsy. Consequent amelioration of the hemodynamic deficit in the ischemic limb was documented by improvement in the calf blood pressure ratio (ischemic/normal limb) to $0.70 \pm 0.08$ in the VEGF-transfected group versus $0.50 \pm 0.18$ in controls $(p<0.05)$. Similar findings were achieved with the 121 and 189 VEGF isoforms (32). These findings thus established that site-specific arterial gene transfer can be used to achieve physiologically meaningful therapeutic modulation of vascular disorders, including therapeutic angiogenesis. More recently, we have used direct intramuscular injection of the plasmid phVEGF ${ }_{165}$ to increase neovascularization in the same rabbit ischemic hind limb model (33). Thirty days after the intramuscular injection of $500 \mu \mathrm{g}$ of phVEGF ${ }_{165}$, angiographically recognizable collateral vessels and histologically identifiable capillaries were increased in 
VEGF-transfected animals compared with controls. This augmented vascularity improved perfusion to the ischemic limb, documented by a superior calf blood pressure ratio for phVEGF $_{165}$ versus controls, improved blood flow in the ischemic limb (measured with an intra-arterial Doppler wire), and increased number of microspheres in the ischemic adductor muscle.

The relevance of these findings in the rabbit ischemic hindlimb model is supported by recent clinical applications of gene therapy (34). Critical limb ischemia is estimated to develop in approximately 500-1000 individuals per million per year (35). In a considerable proportion of these patients, the anatomic extent and distribution of arterial occlusive disease is unsuitable for operative or percutaneous revascularization and is thus frequently followed by an inexorable downhill course $(36,37)$. No pharmacological treatment has been shown to favorably affect the natural history of critical limb ischemia (38). Indeed, amputation, despite its associated morbidity, mortality, and functional implications $(35,39-41)$, is often recommended as a solution to the disabling symptoms-particularly excruciating ischemic rest pain-of critical limb ischemia (42-45). We first investigated the feasibility of arterial gene transfer of VEGF in patients with critical limb ischemia. Using a dose-escalating design, treatment was initiated with $100 \mu \mathrm{g}$ of phVEGF. Three patients presenting with rest pain (but no gangrene) and treated with $1000 \mu \mathrm{g}$ were subsequently shown at 1-year follow-up to have improved blood flow to the ischemic limb and they remain free of rest pain. With the increase in dose of phVEGF 165 to $2000 \mu \mathrm{g}$, angiographic (Fig. 1) and histologic evidence of new blood vessel formation became apparent (46). More recently, the use of intramuscular gene transfer, employed initially as a means of treating patients in whom vascular disease in the ischemic limb was too extensive to permit an intraarterial approach, resulted in marked improvement in collateral vessel development in patients with critical limb ischemia (47). Gene transfer was performed in ten limbs of nine patients with nonhealing ischemic ulcers $(n=7 / 10)$ and/or rest pain $(n=10 / 10)$ due to peripheral arterial disease. A total dose of $4000 \mu \mathrm{g}$ of naked plasmid DNA encoding the 165 amino acid isoform of human vascular endothelial growth factor $\left(\right.$ phVEGF $\left._{165}\right)$ was injected directly into the muscles of the ischemic limb. Gene expression was documented by a transient increase in serum levels of VEGF monitored by ELISA assay

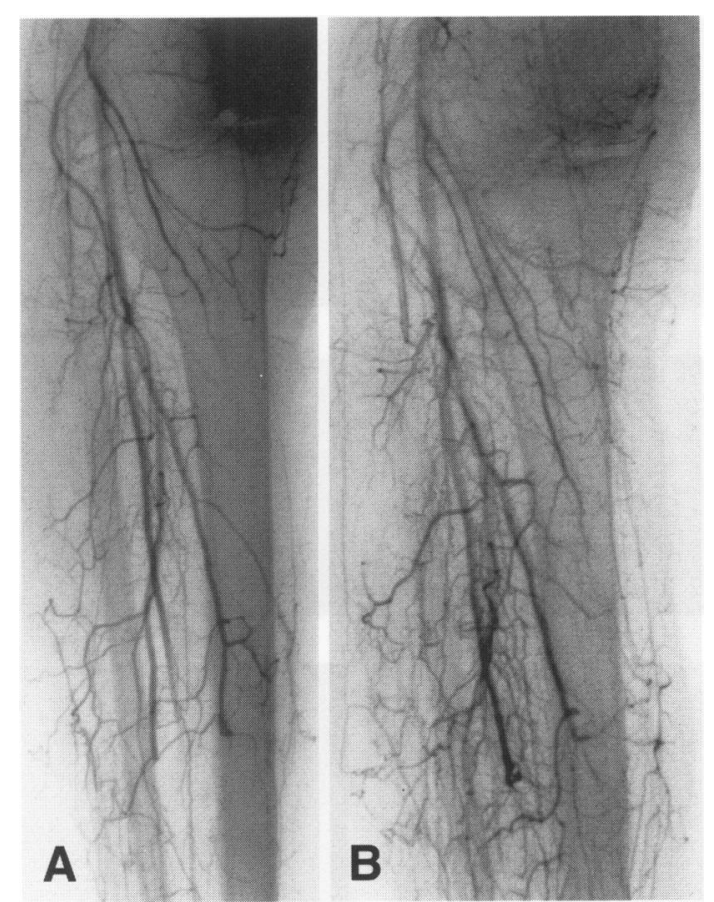

Fig. 1. Selective digital subtraction angiograms performed in a patient with critical limb ischemia due to occlusion of all three infrapopliteal vessels at mid-calf level. (A) Immediately prior to, and (B) 1 month post-gene therapy with $2000 \mu \mathrm{g}$ of naked DNA encoding VEGF. The latter angiogram disclosed a plethora of new collateral vessels in the ischemic limb.

(Fig. 2). The ankle-brachial index improved significantly $(0.33 \pm 0.05$ to $0.48 \pm 0.03, p=0.02$; Fig. 2); newly visible collateral blood vessels were directly documented by contrast angiography in seven limbs; and magnetic resonance angiography showed qualitative evidence of improved distal flow in eight limbs. Ischemic ulcers healed or markedly improved in four of seven limbs, including successful limb salvage in three patients recommended for below-knee amputation (Fig. 2). Tissue specimens obtained from an amputee 10 weeks after gene therapy showed foci of proliferating endothelial cells by immunohistochemistry. PCR and Southern blot analyses indicated persistence of small amounts of plasmid DNA. Complications were limited to transient lower-extremity edema in six patients, which is consistent with VEGF-enhancement of vascular permeability. These findings may be cautiously interpreted to indicate that intramuscular injection of naked plasmid DNA achieves constitutive overexpression of VEGF sufficient to induce therapeutic angiogenesis in selected patients with critical limb ischemia. 

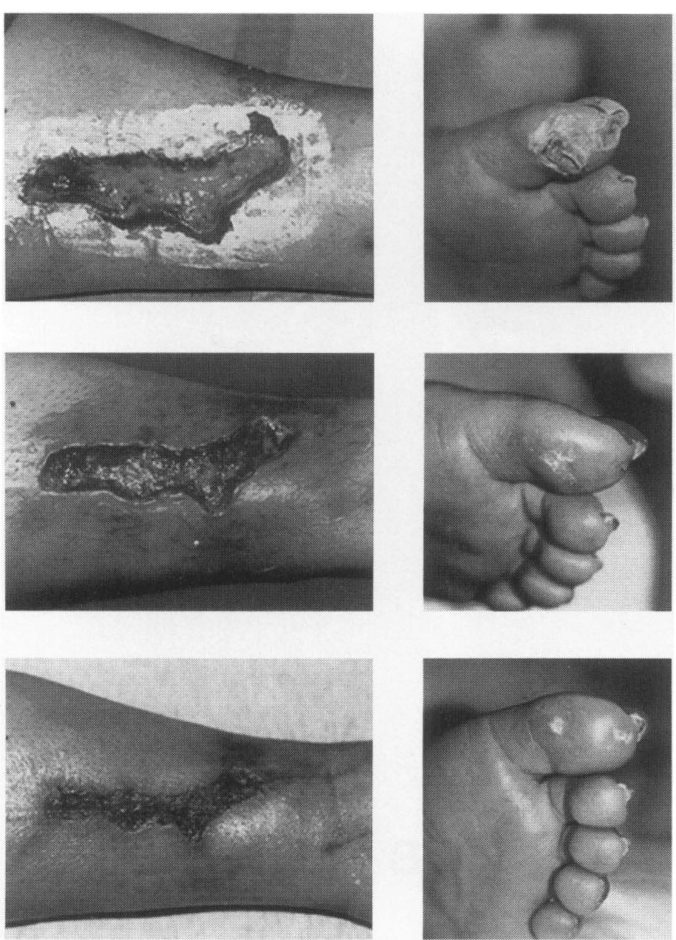

Fig. 2. Limb salvage after gene therapy in a 33-year-old woman. (Left top) Nonhealing wound on the medial aspect of the calf and ischemic necrosis involving the great toe. (Left middle) Ingrowth of granulation tissue in calf wound, healing of great toe. (Left bottom) Three months after gene transfer, healing of split-thickness skin graft at wound site, and full resolution of great toe necrosis. (Right) Evidence of phVEGF ${ }_{165}$ bioavailability documented by an increase in venous VEGF blood levels,

GENE TRANSFER USING VIRAL VECTORS. Among the different viral vectors, replication-defective adenoviruses have been widely used to deliver genes because they can be grown to high titers, exhibit a high transfection efficiency, and can transfect both replicating and quiescent cells. For therapeutic angiogenesis, an adenovirus expressing human FGF-5 was used in a swine model of chronic myocardial ischemia and was shown to increase blood flow to the ischemic region and to improve contractile performance (48). More recently, an adenoviral vector expressing the VEGF $_{121}$ cDNA was shown to induce collateral vessel development in swine ischemic myocardium, resulting in significant improvement in both myocardial perfusion and function (49).

\section{Recombinant Protein versus Gene Therapy}

There are now abundant data from animal models to support the potential utility of both recom-

\section{Pulse Volume Recording (Great Toe)}

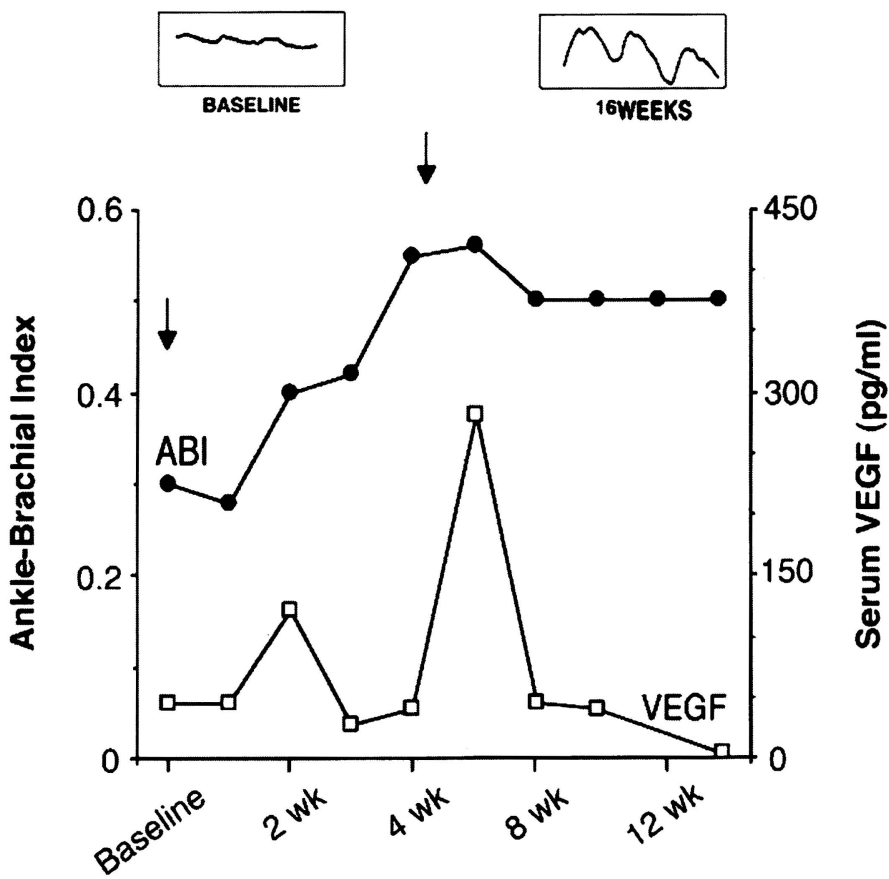

and bioactivity expressed as an increase in anklebrachial index. The ankle-brachial index progressively increased from 0.28 before to 0.56 after gene therapy (weeks refer to time post-transfection). This was associated with the development of a phasic pulse volume recording (PVR) compared with the nonphasic tracing recorded at baseline. Vertical arrows indicate timing of each of the two intramuscular phVEGF ${ }_{165}$ injections.

binant protein therapy and arterial gene transfer for myocardial angiogenesis $(7,14-20,48)$. The same is true for lower-extremity vascular insufficiency $(4-6,12,21-25,50)$. It is therefore reasonable to ask why, if the recombinant protein has or can be manufactured, consider transferring the gene encoding that protein (i.e., gene therapy)? There are at least four issues to consider in this regard. First, and perhaps most critical in the case of arterial gene therapy, is the potential requirement to maintain an optimally high and local concentration over time. In the case of therapeutic angiogenesis, for example, it may be preferable to deliver a lower dose over a period of several days or more from an actively expressing transgene in the ischemic limb, rather than a single or multiple bolus doses of recombinant protein. Second, there is the matter of economics; namely, which therapy would ultimately cost more to develop, implement, and reimburse, particularly for those indications re- 
quiring multiple or even protracted treatment? Third, in certain species-namely rats, rabbits, and swine-both rhbFGF and rhVEGF have been shown to produce varying degrees of systemic hypotension, even in the setting of hypercholesterolemia $(16,51-53)$. This could be a limitation to the clinical application of this type of therapy, although a recent human study showed that the hemodynamic response to rhVEGF could be attenuated by intravenous infusion compared with bolus injection (54). And fourth, the route of administration may be a factor depending upon the target site for neovascularization. For example, the ready access to ischemic skeletal muscle together with the promising results of IM gene therapy make this approach eminently suitable for the treatment of lowerextremity vascular insufficiency. In contrast, IM administration for myocardial angiogenesis cannot be accomplished as readily, and may therefore be more amenable to recombinant protein therapy.

\section{Endothelial Cell Proliferation in Therapeutic Angiogenesis}

A fundamental issue in therapeutic angiogenesis is the relative contribution of pre-existing, albeit "unused," collateral vessels versus new vessel formation to newly visible collaterals, which are seen in the setting of tissue ischemia. It is clear that in animal models, particularly dogs, and in humans, pre-existing collateral channels remain available to perfuse ischemic tissues, even though these channels may show no discernable evidence of blood flow by conventional testing. Conversely, many animal studies have shown that the magnitude of endothelial cell (EC) and smooth muscle cell (SMC) proliferation may be significantly augmented by therapeutic angiogenesis (4). Graham et al. established arteriovenous (AV) fistulae at the popliteal level in a canine model of hind limb ischemia, after which the vein proximal to the AV anastomosis was ligated; this so-called arteriovenous reversal (AVR) was designed to augment perfusion to the distal limb in a retrograde manner (55). A consistent feature of this procedure [in humans (56) as well as animals] was the development of an extensive network of new vessels in the proximity of the AV anastomosis. A significant increase in uptake of tritiated thymidine, administered 3 hr prior to death, was observed in hind limbs treated by AVR versus controls, and, when coupled with histologic evidence of increased cap- illary density, was interpreted as evidence for therapeutically augmented EC proliferation. More recently, Unger et al. (15) administered bromodeoxyuridine (BrdU) to dogs in which collateral artery development had been provoked by application of an ameroid constrictor around the left circumflex coronary artery; after administration of bFGF directly into the circumflex distal to the constrictor, cellular proliferation was found to be increased in collateral-dependent, viable myocardium as well as in sites of myocardial infarction. According to the morphology and location, cells immunopositive for BrdU were judged to consist predominantly of ECs.

Administration of VEGF by Takeshita et al. was shown to augment EC proliferation in midzone collateral vessels $(57)$ by roughly 3 -fold compared with control animals (58); this difference was most profound-and statistically significant-at day 5 post-VEGF. The increase in EC proliferation observed at day 5 post-VEGF was followed by a reduction in the hemodynamic deficit in the ischemic limb by day 7 . Despite the fact that the mitogenic effects of VEGF have been previously shown to be limited to ECs $(10,59)$, the proliferative activity of SMCs in the midzone collaterals also increased by approximately 3 -fold. The augmentation in midzone SMC proliferation at day 5 was statistically significant, compared with that observed in naturally occurring collateral artery development in the present study, and it also exceeds that reported in previous studies of natural collateral development (60-62).

Whereas VEGF has been shown to interact with lower-affinity binding sites to induce mononuclear phagocyte chemotaxis $(63,64)$, higheraffinity binding sites presumed to mediate the mitogenic effects of VEGF are limited to ECs $(10,53)$. Increased SMC proliferation is therefore not likely to represent a direct effect of VEGF. Two indirect effects are possible. It is possible that extravasation of certain angiogenic growth factors due to VEGF-induced permeability from circulating blood might result in the activation of SMC proliferation. Alternatively, ECs stimulated by VEGF may secrete factor(s) that promote SMC proliferation. It has been previously shown, for example, that VEGF induces expression of tissue-type plasminogen activators (t-PA)potent mitogens for cultured human SMCs (65) -in cultured bovine microvascular ECs (66). Platelet-derived growth factor (PDGF), a mitogen and chemoattractant for vascular SMCs (67), which is expressed by ECs $(68-70)$ in a polarized manner (71) sufficient to provide an 

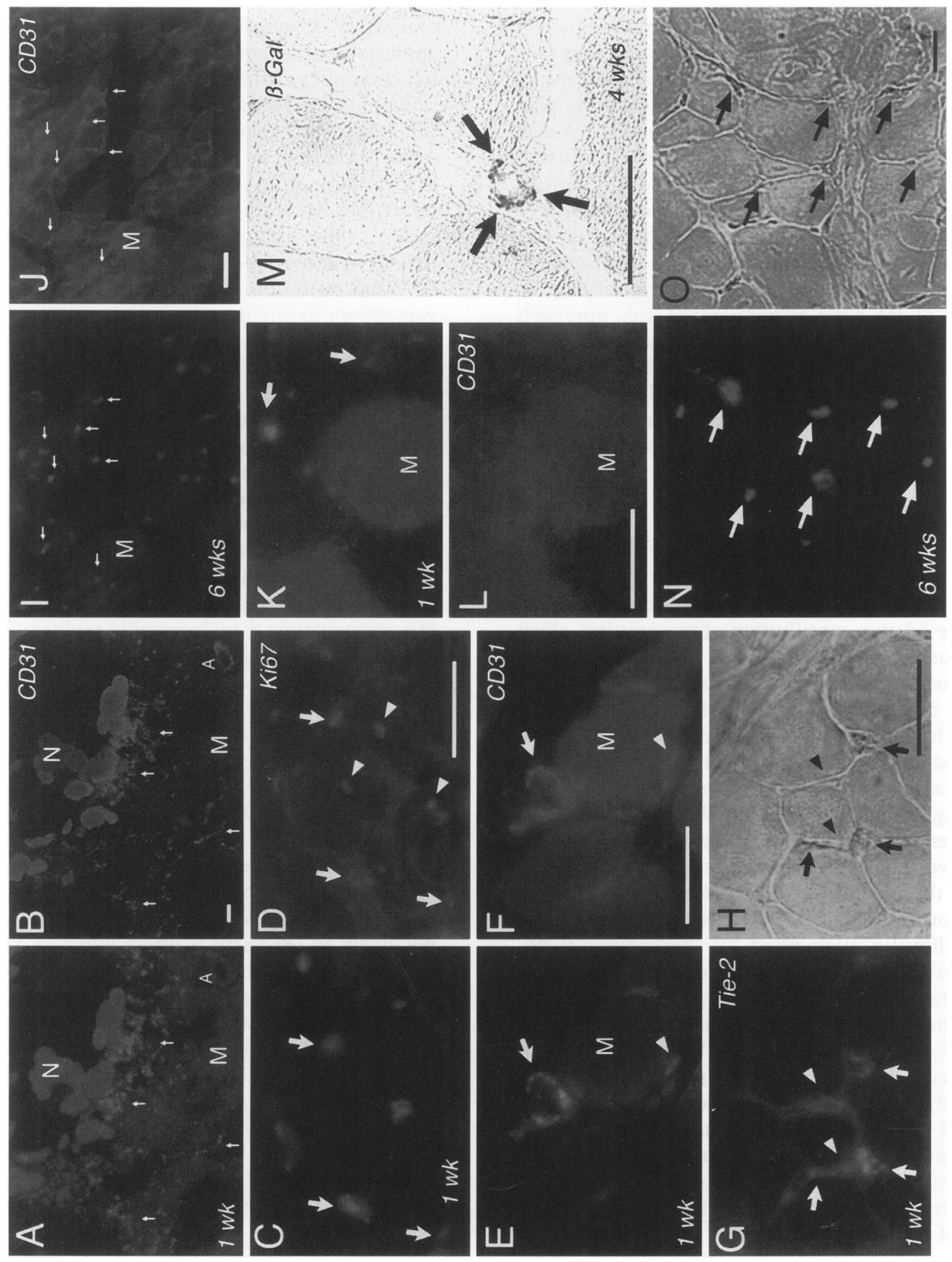
organizing gradient for SMCs, has been previously shown to be induced in human umbilical vein ECs by the addition of another angiogenic growth factor, aFGF (72); experiments performed in our laboratory have shown that VEGF may similarly up-regulate PDGF. Moreover, Stavri et al. (73) have shown that VEGF may similarly up-regulate bFGF, which is also mitogenic for SMCs (74).

\section{EC Migration in Therapeutic Angiogenesis}

During angiogenesis, migration always precedes proliferation by approximately $24 \mathrm{hr}(75)$. In a classic experiment performed in the rat cornea, Sholley et al. (76) showed that vascular sprouting could be induced and continue for more than 2 days, despite irradiation treatment sufficient to suppress DNA synthesis. Angiogenic activity in this model was thus interpreted to reflect the dominant impact of EC migration. Similar implications resulted from recent experiments performed with growth factors that were shown to have a preponderant effect on endothelial cell migration, as opposed to proliferation. A recent member of the vascular endothelial family of growth factors, VEGF-C, was initially thought be a specific ligand for lymphatic endothelium. This was based on the fact that overexpression of
VEGF-C in the skin of transgenic mice resulted in lymphatic vessel hyperplasia without any evidence of angiogenesis (77). We recently evaluated the bioactivity of VEGF-C (78) by performing proliferation and migration assays on different EC types in vitro. We observed clear mitogenic and chemotactic responses of ECs to VEGF-C, in agreement with previous reports $(79,80)$. While the impact on cell migration was similar for VEGF-A and VEGF-C, the proliferative response to VEGF-C was less than that observed for VEGF-A, particularly in the case of human umbilical vein endothelial cells (HUVECs). In spite of the latter, in vivo angiogenesis observed in response to VEGF-C administration in a rabbit ischemic hindlimb model was robust and indistinguishable from that observed previously in the same animal model using VEGF-A recombinant protein (4) or plasmid DNA (32). Similarly, Angiopoietin-1, the recently discovered ligand for the Tie 2 receptor, was shown to be chemotactic for endothelial cells but exhibited no proliferative effect in vitro (81). Nevertheless, using the mouse cornea model (82), and in a rabbit ischemic hindlimb model (83), we have demonstrated that this growth factor has angiogenic properties in vivo. The fact that the in vivo results of these experiments better parallel in vitro analyses of migra-
Fig. 3. Heterologous (A-L), homologous (M), or autologous $(\mathrm{N}, \mathrm{O}) \mathrm{EC}$ progenitors incorporate into sites of angiogenesis in vivo. $(A, B)$ $\mathrm{CD} 34^{+}$mononuclear peripheral blood cells $\left(\mathrm{MB}^{\mathrm{CD} 34+}\right)$ (red, arrows), labeled with the floursecent dye DiI, between skeletal myocytes (M), including necrotic $(\mathrm{N})$ myocytes 1 week after injection; most are colabeled with CD31 (green, arrows). Note pre-existing artery (small A), identified as CD31-positive, but DiI-negative. (C and D) Evidence of proliferative activity among several DiI-labeled $\mathrm{MB}^{\mathrm{CD} 34+}$ derived cells (red, arrows), indicated by coimmunostaining for Ki67 antibody (green). Proliferative activity is also seen among DiI-negative, Ki67-positive capillary ECs (arrowheads); both cell types comprise neovasculature. (E) DiI (red) and CD31 (green) in capillary ECs (arrow, arrowhead) between skeletal myocytes, photographed through double filter 1 week after DiI-labeled $M B^{C D 34+}$ injection. (F) Single green filter shows CD3l (green) expression in DiI-labeled capillary ECs, integrated into capillary with native (DiI-negative, CD31-positive) ECs (arrow, arrowhead). (G) Immunostaining 1 week after $\mathrm{MB}^{\mathrm{CD} 34+}$ injection showing capillaries comprised of DiI-labeled $\mathrm{MB}^{\mathrm{CD} 34+}$-derived cells expressing Tie-2 receptor (green). Several MB $\mathrm{MBD}^{\mathrm{C} 34+}$ derived cells (arrows) are Tie- 2 positive and are inte- grated with some Tie-2-positive host capillary cells (arrowheads) identified by the absence of red fluorescence. $(\mathrm{H})$ Phase-contrast photomicrograph of same tissue section shown in G indicates corresponding DiI-labeled (arrows) and -unlabeled (arrowheads) capillary ECs. (I, J) Six weeks after administration, $\mathrm{MB}^{\mathrm{CD} 34+}$-derived cells (red) colabel for CD31 in capillaries between preserved skeletal myocytes. $(\mathrm{K}, \mathrm{L})$ One week after injection of $\mathrm{MB}^{\mathrm{CD} 34-}$, isolated $\mathrm{MB}^{\mathrm{CD} 34-}$-derived cells (red, arrows) are observed between myocytes, but do not express CD31. (M) Immunostaining of $\beta$-galactosidase in tissue section harvested from ischemic muscle of $\mathrm{B} 6,129$ mice 4 weeks after administration of $\mathrm{MB}^{\mathrm{Flk}-1+}$ isolated from transgenic mice constitutively expressing $\beta$-gal. (Flk-1 cell isolation was used for selection of EC progenitors because of a lack of a suitable anti-mouse CD34 antibody.) Cells overexpressing $\beta$-gal (arrows) have been incorporated into capillaries and small arteries; these cells were identified as ECs by antiCD31 and anti-BS-1 lectin. (N, O) Sections of muscles harvested from rabbit ischemic hindlimb 4 weeks after administration of autologous $\mathrm{MB}^{\mathrm{CD} 34+}$ Red fluorescence indicates localization of $\mathrm{MB}^{\mathrm{CD} 34+}$. derived cells in capillaries, seen (arrows) in phasecontrast photomicrograph $(\mathrm{O})$. Each scale bar indicates $50 \mu \mathrm{m}$. 
tion as opposed to proliferation is consistent with notions regarding the relative contribution of these activities to angiogenesis.

\section{Vasculogenesis}

Postnatal neovascularization has been previously considered to result exclusively from the proliferation, migration, and remodeling of fully differentiated ECs derived from pre-existing blood vessels, i.e., angiogenesis $(60,84,85)$. The formation of blood vessels from EC progenitors, or angioblasts-i.e., vasculogenesis-has been considered restricted to embryogenesis $(86,87)$. We reasoned, however, that the use of hematopoietic stem cells (HSCs) derived from peripheral blood in lieu of bone marrow to provide sustained hematopoietic recovery constituted inferential evidence for circulating stem cells (88). Given the common ancestry of HSCs and angioblasts, we investigated the hypothesis that stem cells circulating in peripheral blood might under selected circumstances differentiate into ECs $(89,90)$. Flk-1 and a second antigen, CD-34, shared by angioblasts and HSCs (91-102) were used to isolate putative angioblasts from the leukocyte fraction of peripheral blood. In vitro, these cells differentiated into ECs. In animal models of ischemia, heterologous, homologous, and autologous EC progenitors incorporated into sites of active angiogenesis (Fig. 3). These findings thus suggest that circulating EC progenitors may contribute to neoangiogenesis in adult species, consistent with vasculogenesis.

Parenthetically, these findings may have implications for augmenting collateral vessel growth to ischemic tissues (therapeutic vasculogenesis) and for delivery of pro-angiogenic agents to sites of pathologic or utilitarian angiogenesis. A potentially limiting factor in strategies designed to promote neovascularization of ischemic tissues (46) is the resident population of ECs that is competent to respond to administered angiogenic cytokines. This issue may be successfully addressed with autologous EC transplants. The fact that progenitor ECs home to foci of angiogenesis suggests potential utility as autologous vectors for gene therapy. For treatment of regional ischemia, angiogenesis could be amplified by transfection of $\mathrm{CD} 34^{+}$mononuclear peripheral blood cells to achieve constitutive expression of angiogenic cytokines and/or provisional matrix proteins (103).

\section{Conclusions}

The proof of principle has now been established that therapeutic angiogenesis can be achieved in animal models of myocardial and hind limb ischemia. Moreover, recent clinical studies suggest that patients with severe forms of ischemic vascular disease could potentially benefit from such therapies. The advent of therapeutic angiogenesis has generated controversy with regard to protein versus gene therapy. Resolution of this issue will almost certainly require the empirical experience of human clinical trials. Recombinant FGF and VEGF are now being investigated in human clinical trials for patients with lower-extremity vascular disease and myocardial ischemia, so the magnitude of bioactivity that can be achieved with either of these should be ultimately clarified. Our understanding of postnatal neovascularization is in constant evolution. The discovery of new angiogenic growth factors (VEGF-C, Angiopoietin), and new conceptual mechanisms of neovessel formation (postnatal vasculogenesis), will directly influence the development of new therapeutic strategies to promote neovascularization in ischemic vascular diseases.

\section{References}

1. Gilbert SF. (1997) Developmental Biology, 4th ed. Sunderland, MA: Sinauer Associates.

2. D'Amore PA, Thompson RW. (1987) Mechanisms of angiogenesis. Annu. Rev. Physiol. 49: 453-464.

3. Folkman J. (1971) Tumor angiogenesis: Therapeutic implications. N. Engl. J. Med. 285: $1182-$ 1186.

4. Takeshita S, Zheng LP, Brogi E, et al. (1994) Therapeutic angiogenesis: A single intra-arterial bolus of vascular endothelial growth factor augments revascularization in a rabbit ischemic hindlimb model. J. Clin. Invest. 93: 662-670.

5. Baffour R, Berman J, Garb JL, Rhee SW, Kaufman J, Friedmann P. (1992) Enhanced angiogenesis and growth of collaterals by in vivo administration of recombinant basic fibroblast growth factor in a rabbit model of acute lower limb ischemia: Dose-response effect of basic fibroblast growth factor. J. Vasc. Surg. 16: 181-191.

6. Pu LQ, Sniderman AD, Brassard R, et al. (1993) Enhanced revascularization of the ischemic limb by means of angiogenic therapy. Circulation 88: 208-215.

7. Yanagisawa-Miwa A, Uchida Y, Nakamura F, et al. (1992) Salvage of infarcted myocardium by angiogenic action of basic fibroblast growth factor. Science 257: 1401-1403. 
8. Levy AP, Tamargo R, Brem H, Nathans D. (1989) An endothelial cell growth factor from the mouse neuroblastoma cell line NB41. Growth Factors 2: 9-19.

9. Connolly DT, Hewelman DM, Nelson R, et al. (1989) Tumor vascular permeability factor stimulates endothelial cell growth and angiogenesis. J. Clin. Invest. 84: 1470-1478.

10. Ferrara N, Henzel WJ. (1989) Pituitary follicular cells secrete a novel heparin-binding growth factor specific for vascular endothelial cells. Biochem. Biophys. Res. Commun. 161: 851-855.

11. Pu LQ, Jackson S, Lachapelle KJ, et al. (1994) A persistent hindlimb ischemia model in the rabbit. J. Invest. Surg. 7: 49-60.

12. Takeshita S, Pu L-Q, Zheng L, et al. (1994) Vascular endothelial growth factor induces dose-dependent revascularization in a rabbit model of persistent limb ischemia. Circulation 90: II-228II-234.

13. Bauters C, Asahara T, Zheng LP, et al. (1994) Physiologic assessment of augmented vascularity induced by VEGF in ischemic rabbit hindlimb. Am. J. Physiol. 267: H1263-H1271.

14. Banai S, Jaklitsch MT, Shou M, et al. (1994) Angiogenic-induced enhancement of collateral blood flow to ischemic myocardium by vascular endothelial growth factor in dogs. Circulation 89: 2183-2189.

15. Unger EF, Banai S, Shou M, et al. (1994) Basic fibroblast growth factor enhances myocardial collateral flow in a canine model. Am. J. Physiol. 266: H1588-H1595.

16. Hariawala M, Horowitz JR, Esakof D, et al. (1996) VEGF improves myocardial blood flow but produces EDRF-mediated hypotension in porcine hearts. J. Surg. Res. 63: 77-82.

17. Pearlman JD, Hibberd MG, Chuang ML, et al. (1995) Magnetic resonance mapping demonstrates benefits of VEGF-induced myocardial angiogenesis. Nature Med. 1: 1085-1089.

18. Selke FW, Jianyi L, Stamler A, Lopez JJ, Thomas KA, Simons M. (1996) Angiogenesis induced by acidic fibroblast growth factor as an alternative method of revascularization for chronic myocardial ischemia. Surgery 120: 182-188.

19. Sellke FW, Wang SY, Friedman M, et al. (1994) Basic FGF enhances endothelium-dependent relaxation of the collateral-perfused coronary microcirculation. Am. J. Physiol. 267: H1303H1311.

20. Harada K, Grossman W, Friedman $M$, et al. (1994) Basic fibroblast growth factor improves myocardial function in chronically ischemic porcine hearts. J. Clin. Invest. 94: 623-630.

21. Asahara T, Bauters C, Zheng LP, et al. (1995) Synergistic effect of vascular endothelial growth factor and basic fibroblast growth factor on angiogenesis in vivo. Circulation 92: II-365-II-371.

22. Bauters C, Asahara T, Zheng LP, et al. (1995)
Site-specific therapeutic angiogenesis following systemic administration of vascular endothelial growth factor. J. Vasc. Surg. 21: 314-325.

23. Van Belle E, Witzenbichler B, Chen D, Silver $M$, Chang L, Schwall R, Isner JM. (1998) Potentiated angiogenic effect of scatter factor/hepatocyte growth factor via induction of vascular endothelial growth factor. Circulation 97: 381-390.

24. Yang HT, Deschenes MR, Ogilvie RW, Terjung RL. (1996) Basic fibroblast growth factor increases collateral blood flow in rats with femoral arterial ligation. Circ. Res. 79: 62-69.

25. Walder CE, Errett CJ, Ogez J, et al. (1996) Vascular endothelial growth factor (VEGF) improves blood flow and function in a chronic ischemic hind limb model. J. Cardiovasc. Pharmacol. 27: 91-98.

26. Schumacher B, Pecher P, von Specht BU, Stegmann TH. (1998) Induction of neoangiogenesis in ischemic myocardium by human growth factors: First clinical results of a new treatment of coronary heart disease. Circulation 97: 645-650.

27. Tischer E, Mitchell R, Hartmann T, et al. (1991) The human gene for vascular endothelial growth factor: Multiple protein forms are encoded through alternative exon splicing. J. Biol. Chem. 266: 11947-11954.

28. Losordo DW, Pickering JG, Takeshita S, et al. (1994) Use of the rabbit ear artery to serially assess foreign protein secretion after site specific arterial gene transfer in vivo: Evidence that anatomic identification of successful gene transfer may underestimate the potential magnitude of transgene expression. Circulation 89: 785-792.

29. Takeshita S, Losordo DW, Kearney M, Isner JM. (1994) Time course of recombinant protein secretion following liposome-mediated gene transfer in a rabbit arterial organ culture model. Lab. Invest. 71: 387-391.

30. Riessen $\mathrm{R}$, Rahimizadeh $\mathrm{H}$, Blessing $\mathrm{E}$, Takeshita S, Barry JJ, Isner JM. (1993) Arterial gene transfer using pure DNA applied directly to a hydrogel-coated angioplasty balloon. Hum. Gene Ther. 4: 749-758.

31. Takeshita S, Weir L, Chen D, et al. (1996) Therapeutic angiogenesis following arterial gene transfer of vascular endothelial growth factor in a rabbit model of hindlimb ischemia. Biochem. Biophys. Res. Commun. 227: 628-635.

32. Takeshita S, Tsurumi $\mathrm{Y}$, Couffinhal $\mathrm{T}$, et al. (1996) Gene transfer of naked DNA encoding for three isoforms of vascular endothelial growth factor stimulates collateral development in vivo. Lab. Invest. 75: 487-502.

33. Tsurumi Y, Chen D, Silver M, et al. (1997) Treatment of acute limb ischemia by intramuscular injection of vascular endothelial growth factor gene. Circulation 96: II-382-II-388.

34. Isner JM, Walsh K, Symes J, et al. (1996) Arterial gene transfer for therapeutic angiogenesis in pa- 
tients with peripheral artery disease. Hum. Gene Ther. 7: 959-988.

35. European Working Group on Critical Leg Ischemia. (1991) Second European consensus document on chronic critical leg ischemia. Circulation 84: IV-1-IV-26.

36. Dormandy J, Mahir M, Ascady G, et al. (1989) Fate of the patient with chronic leg ischaemia. J. Cardiovasc. Surg. 1: 50-57.

37. Rutherford RB, Flanigan DP, Gupta SK, et al. (1986) Ad Hoc Committee on Reporting Standards, Society for Vascular Surgery/North American Chapter, International Society for Cardiovascular Surgery. J. Vasc. Surg. 4: 80-94.

38. Isner JM, Rosenfield K. (1993) Redefining the treatment of peripheral artery disease. Circulation 88: 1534-1557.

39. Most RS, Sinnock P. (1983) The epidemiology of lower extremity amputations in diabetic individuals. Diabetes Care 6: 87-91.

40. Taylor LM Jr, Porter JM. (1995) Natural history and non-operative treatment of chronic lower extremity ischemia. In: Rutherford RB (ed). Vascular Surgery. W.B. Saunders, Philadelphia, 751766.

41. Wolfe JHN. (1986) Defining the outcome of critical ischemia: A one-year prospective study. $B r . J$. Surg. 73: 321-328.

42. Eneroth M, Persson BM. (1992) Amputation for occlusive arterial disease. A multicenter study of 177 amputees. Int. Orthop. 16: 382-387.

43. Campbell WB, Johnston JA, Kernick VF, Rutter EA. (1994) Lower limb amputation: Striking the balance. Ann. R. Coll. Surg. Engl. 76: 205-209.

44. Dawson I, Keller BP, Brand R, Pesch-Batenburg J, Hajo van Bockel J. (1995) Late outcomes of limb loss after failed infrainguinal bypass. J. Vasc. Surg. 21: 613-622.

45. Skinner JA, Cohen AT. (1996) Amputation for premature peripheral atherosclerosis: Do young patients do better? Lancet 348: 1396.

46. Isner JM, Pieczek A, Schainfeld R, et al. (1996) Clinical evidence of angiogenesis following arterial gene transfer of phVEGF ${ }_{165}$. Lancet 348: 370374.

47. Baumgartner I, Pieczek A, Manor O, et al. (1998) Constitutive expression of phVEGF ${ }_{165}$ following intramuscular gene transfer promotes collateral vessel development in patients with critical limb ischemia. Circulation 97: 1114-1123.

48. Giordano FJ, Ping P, McKirnan D, et al. (1996) Intracoronary gene transfer of fibroblast growth factor-5 increases blood flow and contractile function in an ischemic region of the heart. $\mathrm{Na}$ ture Med. 2: 534-539.

49. Mack CA, Patel SR, Schwarz EA, et al. (1998) Biologic bypass with the use of adenovirus-mediated gene transfer of the complementary deoxyribonucleic acid for vascular endothelial growth factor 121 improves myocardial perfu- sion and function in the ischemic porcine heart. J. Thorac. Cardiovasc. Surg. 115: 168-176.

50. Tabata H, Silver M, Isner JM. (1997) Arterial gene transfer of acidic fibroblast growth factor for therapeutic angiogenesis in vivo: Critical role of secretion signal in use of naked DNA. Cardiovasc. Res. 35: 470-479.

51. Cuevas P, Carceller F, Ortega S, Zazo M, Nieto I, Gimenez-Gallego G. (1991) Hypotensive activity of fibroblast growth factor. Science 254: 1208 1210.

52. Yang R, Bunting S, Ko A, Keyt B, Jin H. (1995) Hemodynamic effects of vascular endothelial growth factor in conscious rats [Abstract]. Circulation 92: I-659.

53. Horowitz JR, Rivard A, van der Zee R, Hariawala M, Sheriff DD, Esakof D, Chaudhry GM, Symes JF, Isner JM. (1997) Vascular endothelial growth factor/vascular permeability factor produces nitric oxide-dependent hypotension. Arterioscler. Thromb. Vasc. Biol. 17: 2793-2800.

54. Yang R, Bunting S, Ko A, et al. (1997) Substantially attenuated hemodynamic responses to Escherichia coli-derived vascular endothelial growth factor given by intravenous infusion compared with bolus injection. J. Pharmacol. Exp. Ther. 284: 103-110.

55. Graham AM, Baffour R, Burdon T, et al. (1989) A demonstration of vascular proliferation in response to arteriovenous reversal in the ischemic canine hind limb. J. Surg. Res. 47: 341-347.

56. Symes JF, Graham AM, Stein L, Sniderman AD. (1984) Salvage of a severely ischemic limb by arteriovenous revascularization: A case report. Can. J. Surg. 27: 274-276.

57. Longland CJ. (1953) The collateral circulation of the limb. Ann. R. Coll. Surg. Engl. 13: 161-181.

58. Takeshita S, Rossow ST, Kearney M, et al. (1995) Time course of increased cellular proliferation in collateral arteries following administration of vascular endothelial growth factor in a rabbit model of lower limb vascular insufficiency. Am. J. Pathol. 147: 1649-1660.

59. Conn G, Soderman D, Schaeffer M-T, Wile M, Hatcher VB, Thomas KA. (1990) Purification of glycoprotein vascular endothelial cell mitogen from a rat glioma cell line. Proc. Natl. Acad. Sci. U.S.A. 87: 1323-1327.

60. Schaper W, Brahander MD, Lewi P. (1971) DNA synthesis and mitoses in coronary collateral vessels of the dog. Circ. Res. 28: 671-679.

61. Pasyk S, Schaper W, Schaper J, Pasyk K, Miskiewicz G, Steinseifer B. (1982) DNA synthesis in coronary collaterals after coronary artery occlusion in conscious dog. Am. J. Physiol. 242: H1031-H1037.

62. Bucay M, Nguy JH, Barrios R, Kerns SA, Henry PD. (1992) Impaired macro- and microvascular growth in hypercholesterolemic rabbits [Abstract]. J. Am. Coll. Cardiol. 19: 151 A. 
63. Clauss M, Gerlach M, Gerlach H, et al. (1990) Vascular permeability factor: A tumor-derived polypeptide that induces endothelial cell and monocyte procoagulant activity, and promotes monocyte migration. J. Exp. Med. 172: 15351545.

64. Shen H, Clauss M, Ryan J, et al. (1993) Characterization of vascular permeability factor/vascular endothelial growth factor receptors on mononuclear phagocytes. Blood 81: 2767-2773.

65. Herbert JM, Lamarche I, Prabonnaud V, Dol F, Gauthier T. (1994) Tissue-type plasminogen activator is a potent mitogen for human aortic smooth muscle cells. J. Biol. Chem. 269: 30763080.

66. Pepper MS, Ferrara N, Orci L, Montesano R. (1991) Vascular endothelial growth factor (VEGF) induces plasminogen activators and plasminogen activator inhibitor-1 in microvascular endothelial cells. Biochem. Biophys. Res. Commun. 181: 902-906.

67. Ross R, Glomset B, Kariya B, Harker L. (1974) A platelet-dependent serum factor that stimulates the proliferation of arterial smooth muscle cells in vitro. Proc. Natl. Acad. Sci. U.S.A. 71: 12071210.

68. Collins T, Ginsburg D, Boss JM, Orkin SH, Pober JS. (1985) Cultured human endothelial cells express platelet-derived growth factor B chain: cDNA cloning and structural analysis. Nature 316: $748-750$.

69. Collins T, Pober JS, Gimbrone MA Jr, Betsholtz C, Westermark B, Heldin C-H. (1987) Cultured human endothelial cells express platelet-derived factor A chain. Am. J. Pathol. 126: 7-12.

70. Bowen-Pope DF, Hart CE, Weifert RA. (1989) Sera and conditioned media contain different isoforms of platelet-derived growth factor (PDGF) which bind to different classes of PDGF receptors. J. Biol. Chem. 264: 2502-2508.

71. Zerwes H-G, Risau W. (1987) Polarized secretion of a platelet-derived growth factor-like chemotactic factor by endothelial cells in vitro. J. Cell Biol. 105: 2037-2041.

72. Gay CG, Winkles JA. (1990) Heparin-binding growth factor-1 stimulation of human endothelial cells induces platelet-derived growth factor A-chain gene expression. J. Biol. Chem. 265: 3284-3292.

73. Stavri GT, Zachary IC, Baskerville PA, Martin JF, Erusalimsky JD. (1995) Basic fibroblast growth factor upregulates the expression of vascular endothelial growth factor in vascular smooth muscle cells: Synergistic interaction with hypoxia. Circulation 92: 11-14.

74. Lindner V, Lappi DA, Baird A, Majack RA, Reidy MA. (1991) Role of basic fibroblast growth factor in vascular lesion formation. Circ. Res. 68: 106113.

75. Ausprunk DH, Folkman J. (1977) Migration and proliferation of endothelial cells in preformed and newly formed blood vessels during tumor angiogenesis. Microvasc. Res. 14: 53-65.

76. Sholley MM, Ferguson GP, Seibel HR, Montour JL, Wilson JD. (1984) Mechanisms of neovascularization: Vascular sprouting can occur without proliferation of endothelial cells. Lab. Invest. 51: 624-634.

77. Jeltsch M, Kaipainen A, Joukov V, et al. (1997) Hyperplasia of lymphatic vessels in VEGF-C transgenic mice. Science 276: 1423-1425.

78. Witzenbichler B, Asahara T, Murohara T, et al. (1998) Vascular endothelial growth factor-C (VEGF-C/VEGF-2) promotes angiogenesis in the setting of tissue ischemia. Am. J. Pathol. (In press).

79. Joukov V, Pajusola K, Kaipainen A, et al. (1996) A novel vascular endothelial growth factor, VEGF-C, is a ligand for the Flt4 (VEGFR-3) and KDR (VEGFR-2) receptor tyrosine kinases. EMBO J. 15: 290-298.

80. Lee J, Gray A, Yuan J, Luoh S, Avraham H, Wood WI. (1996) Vascular endothelial growth factor-related protein: A ligand and specific activator of the tyrosine kinase receptor Flt4. Proc. Natl. Acad. Sci. U.S.A. 93: 1988-1992.

81. Witzenbichler B, Maisonpierre PC, Jones P, Yancopoulos GD, and Isner JM. (1998) Chemotactic properties of angiopoietin-1 and -2, ligands for endothelial-specific receptor tyrosine kinase Tie2. J. Biol. Chem. (In press).

82. Asahara T, Chen D, Takahashi T, et al. (1998) The Tie2 receptor ligands, angiopoietin-1 and angiopoietin-2 modulate VEGF-induced postnatal neovascularization. Circ. Res. (In press).

83. Shyu K-G, Manor O, Magner M, Yancopoulos GD, Isner JM. (1998) Direct intramuscular injection of plasmid DNA encoding angiopoietin-1, but not angiopoietin-2, augments revascularization in the rabbit ischemic hindlimb. Circulation (In press).

84. Folkman J, Shing Y. (1992) Angiogenesis. J. Biol. Chem. 267: 10931-10934.

85. Risau W. (1995) Differentiation of endothelium. FASEB J. 9: 926-933.

86. Risau W, Sariola H, Zerwes H-G, et al. (1988) Vasculogenesis and angiogenesis in embryonic stem cell-derived embryoid bodies. Development 102: 471-478.

87. Pardanaud L, Altman C, Kitos P, Dieterien-Lievre F. (1989) Relationship between vasculogenesis, angiogenesis and haemopoiesis during avian ontogeny. Development 105: 473-485.

88. Asahara T, Murohara T, Sullivan A, et al. (1997) Isolation of putative progenitor endothelial cells for angiogenesis. Science 275: 965-967.

89. Wu MH-D, Shi Q, Wechezak AR, Clowes AW, Gordon IL, Sauvage LR. (1995) Definitive proof of endothelialization of a Dacron arterial prosthesis in a human being. J. Vasc. Surg. 21: 862-867. 
90. Shi Q, Wu MH, Hayashida N, Wechezak AR, Clowes AW, Sauvage LR. (1994) Proof of fallout endothelialization of impervious dacron grafts in the aorta and inferior vena cava of the dog. $J$. Vasc. Surg. 20: 546-556.

91. Civin CI, Banquerigo ML, Strauss LC, Loken MR. (1987) Antigen analysis of hematopoiesis. VI. Flow cytometric characterization of My-10-positive progenitor cells in normal human bone marrow. Exp. Hematol. 15: 10-17.

92. Katz F, Tindle RW, Sutherland DR, Greaves MD. (1985) Identification of a membrane glycoprotein associated with hemopoietic progenitor cells. Leuk. Res. 9: 191-198.

93. Andrews RG, Singer JW, Bernstein ID. (1986) Monoclonal antibody $12-8$ recognizes a $115-\mathrm{kd}$ molecular present on both unipotent and multipotent hematopoietic colony-forming cells and their precursors. Blood 67: 842-845.

94. Fina J, Molgard HV, Robertson D, et al. (1990) Expression of the CD34 gene in vascular endothelial cells. Blood 75: 2417-2426.

95. Soligo D, Delia D, Oriani A, et al. (1991) Identification of $\mathrm{CD}_{3} 4^{+}$cells in normal and pathological bone marrow biopsies by OBEND10 monoclonal antibody. Leukemia 5: 1026-1030.

96. Ito A, Nomura S, Hirota S, Suda T, Kitamura Y. (1995) Enhanced expression of CD34 messenger RNA by developing endothelial cells of mice. $L a b$. Invest. 72: 532-538.

97. deVries C, Escobedo JA, Ueno H, Houck K, Ferrara N, Williams LT. (1992) The fms-like tyrosine kinase, a receptor for vascular endothelial growth factor. Science 255: 989-991.

98. Terman BI, Carrion ME, Kovacs E, Rasmussen BA, Eddy RL, Shows TB. (1991) Identification of a new endothelial cell growth factor receptor tyrosine kinase. Oncogene 6: 1677-1683.

99. Shalaby F, Rossant J, Yamaguchi TP, et al. (1995) Failure of blood-island formation and vasculogenesis in Flk-1 deficient mice. Nature 376: 62-66.

100. Matthews W, Jordan CT, Gavin M, Jenkins NA, Copeland NG, Lemischka IR. (1991) A receptor tyrosine kinase cDNA isolated from a population of enriched primitive hematopoietic cells and exhibiting close genetic linkage to c-kit. Proc. Natl. Acad. Sci. U.S.A. 88: 9026-9030.

101. Millauer B, Wizigmann-Voos S, Schnurch H, et al. (1993) High affinity VEGF binding and developmental expression suggest $F l k-1$ as a major regulator of vasculogenesis and angiogenesis. Cell 72: 835-846.

102. Yamaguchi TP, Dumont DJ, Conlon RA, Breitman ML, Rossant J. (1993) flk-1, and flt-related receptor tyrosine kinase is an early marker for endothelial cell precursors. Development 118: 489-498.

103. Senger DR, Ledbetter SR, Claffey KP, Papadopoulos-Sergiou A, Perruzzi CA, Detmar $M$. (1996) Stimulation of endothelial cell migration by vascular permeability factor/vascular endothelial growth factor through cooperative mechanisms involving the avb3 integrin, osteopontin, and thrombin. Am. J. Pathol. 149: 293-305. 